\title{
Persecution Act as Filter Bubble Effect: Digital Society and The Shift of Public Sphere
}

\author{
Arina Rohmatul Hidayah \\ Department of Communications Science, Faculty of Social and Political Sciences, Universitas Gadjah Mada \\ (email: arinarohmatulh@gmail.com)
}

\begin{abstract}
This article discusses persecution acts associated with the filter bubble effect, the condition of digital society, the concept of the public sphere and the rational action theory of Jurgen Habermas. The results, obtained through the literature research method, show that acts of persecution in social media can be caused by the personalization of the web. Social media allows the occurrence of large bubbles (filter bubbles) that make users reject ideologies or other truths. This becomes a revolution of mindset due to the freedom of information. Meanwhile, in the Habermas public sphere concept, which emphasizes the existence of a critical and rational discussion, this phenomenon indicates a shift. The shift that occurs brings about the lifeworld realm as the basis for the formation of the public sphere with its communicative action, again dominated by the system realm that is dominated by capitalist forces through strategic action. Thus, Habermas's initial goal of strengthening civil society's position against the dominance of the system is now changing.
\end{abstract}

\section{Keywords:}

persecution; filter bubble effect; social media; digital society; public sphere

\section{Introduction}

Still remember clearly how the sovereignty of Indonesia a bit shaky with the events of December 2, 2016 (212) yesterday. On the official site of tirto.id, explained that the action began when Ahok paid a working visit to the Kepulauan Seribu on Tuesday, September 27,2016 . During a speech in front of the people, Ahok said not to force citizens to vote himself in the elections 2017. The statement was accompanied by quotation from Al Maidah verse 51 reaping public reactions. On Thursday, October 6, 2016, Ahok's video about Al Maidah verse 51 was viral on social media, through a Facebook network owned by Buni Yani (Debora, 2016). This case has created tension among the Muslim community who became the majority religion in Indonesia. Jokowi as
Head of Government seeks to consolidate with a number of religious leaders so that the condition of society can be controlled.

In those days the public voice was split between those who thought that Ahok was innocent and those who considered him "toying with" QS. Al-Maidah verse 53. This condition is then allegedly caused many cases of persecution. In the official website, www.ccnindonesia. com, explained that the network of freedom of expression volunteers in Southeast Asia, Safenet noted as many as 59 people have been subjected to target persecution or 'hunt' intimidative postrolling cases of blasphemy that ensnare Basuki Tjahaja Purnama alias Ahok. The so-called 'The Ahok Effect' precision waves appear especially after Ahok is convicted. Safenet has since recorded a drastic rise in reporting referring to 
Article 28 paragraph 2 of the Information and Electronic Transactions Act (Gual, 2017).

Ahok's case is a small part of various other persecution cases. According to Big Indonesian Dictionary, persecution is the arbitrary hunting of a person or a number of citizens and is harmed, harassed, or crushed (www.kbbi. web.id, 2017, para. 1). And interestingly, the persecution is rife in social media as the impact of web personalization or familiarly called filter bubble effect. It must be admitted that social media has complicated algorithms, one click and like methods will determine what information we receive next. Recently others have argued that personalization algorithms used by online services such as Facebook and Google display users similar perspectives and ideas and remove opposing viewpoints on behalf of the users without their consent (Pariser 2011 as cited in Bozdag \& Hoven, 2015, p. 249).

Furthemore, Pariser (2011) mention that this might lead to the situation in which the user receives biased information. In case of political information, it might lead to the situation that the user never sees contrasting viewpoints on a political or moral issue. Users will be placed in a "filter bubble" and they will not even know what they are missing (as cited in Bozdag \& Hoven, 2015, p. 249).

People's life is likely to change since the arrival of new media. Information plays an important role for now, so it is reasonable if the state of society in the digital age referred to as the information society. Digital society has made digital communication and information flow a vital part of everyday life, although access to the Internet and digital technologies varies around the globe (Hansen et al., 2017, p. 80). Through that information, someone has full authority to regulate himself and others will be like what. Includes issues of persecution due to the shackled mindset at a certain point of view. The world is created by someone with information that he gets in social media.
Referring to the above issues, it cannot be separated from the role of social media as a public sphere. Social media becomes a facility for anyone, both ordinary citizens and government officials to connect and communicate as well as the principle of public sphere described by Charles \& Rohwer (2015, p. 1) that this was a space where individuals gathered to discuss with each other, and sometimes with public officials, matters of shared concern. The aim of these gatherings was not simply discourse; these gatherings allowed the bourgeoisie to use their reason to determine the boundaries of public and private and to self-consciously develop the public sphere. The term "discussion" refers to social media as a public sphere that allows for the rational exchange of ideas about policies relating to citizens. Each member engages in critical discussions with different points of view. There is an interaction going on, so a more rational and well-judged argument will be accepted.

From that concept, the phenomenon that occurs today has shifted from the basic function of public sphere. With the act of persecution as a filter bubble effect, indicates the loss of critical power and the absence of arguments. Social media can be a space for anyone to lead public opinion to be the same as their beliefs. Forgings are so strong, something that is consumed every day, even every second, can change a person's perspective. In addition to sparking the concept of public sphere, as a continuation, Habermas also reveals the theory of actor's rational action that emphasize the rationality in the public sphere itself. Divided into two types of actions, namely the act of instrumental rationality and communicative rationality. These two actions can be used as an analytical tool in seeing the persecution act in social media as filter bubble effect.

Departing from this issue, it will be discussed more deeply how acts of persecution in social media are associated with filter bubble 
effect, digital society contexts, actors' rational actions and the loss of critical discussions in public sphere such as Yetkinel \& Colak's (2017, p. 5011) statement that the $18^{\text {th }}$ century concept developed by Jurgen Habermas, where public sphere got to be known for its undiluted, critical nature backed by the power of reasoning.

This discussion is important because not many journal articles have linked the five keywords above. Previous studies have dealt with it more separately, whereas in terms of the fifth concept, they are related to each other, both as cause and effect factors. Such as research from Caplan \& Boyd (2016, p. 15) that only associate algorithms on social media like Facebook and Twitter with the concept of public sphere. From his research shows, all systems of power are manipulated and there is little doubt that public spheres constructed through network technologies and algorithms can be manipulated, both by the architects of those systems and by those who find techniques to shape information flows. On the other hand, there are related research on the persecution associated with online shaming and the right to privacy. This paper advances privacy theory through examination of online shaming, focusing in particular on persecution by internet mobs (Laidlaw, 2017, p. 1). Unfortunately, this research does not include filter bubble effect as the cause of online shaming or basic concept of public sphere that essentially upholds rationality and critical discussion without unilateral thought like the phenomenon.

\section{Literature Review}

\section{Social Media and Digital Society}

Digitalization of media resulted in an interactive platform of social media. Related to the definition, Kaplan \& Haenlein (2010, p. 61) mentions that there is no single definition 'What is Social Media' There is more of a kind of description of what the process of social media by underlying the interaction among people in which they are creating, sharing, exchanging, modifying their ideas in virtual communities or networks: "Social Media is a group of Internet based applications that build on the ideological foundations of Web 2.0, and that allow the creation and exchange of User Generated Content" (as cited in Bank, 2014, p. 1185).

In social media, users have a freedom to access the desired information. Unlike the previous traditional media where information obtained by the public is determined by the media or the so-called agenda setting. They have no authority over what is consumed. What is important for the media to be important also for the audiences. As for now, the statement instead turned what is important for the audiences, is that important for the media. Because, through social media users can determine which topics are most in demand, resulting in a number of traditional media such as television and newspapers are competing proclaimed it. Therefore, the spread of social media platforms provides an opportunity for enhanced access to information and a diversification of sources and opinions. Social media have greatly advanced the possibilities of "citizen journalism". They provide channels for everyone to reach out to the public, to share information, and to express opinions without formal requirements and with a minimum interference in form of regulation and censorship (Kamp, 2016, p. 5).

Furthermore, Dr. William Tayeebwa, Head of the Department of Journalism and Communication at Makerere University, in his keynote address at the KAS Social Media Conference 2015, explained about opportunities and challenges of the use of new media technologies, particularly social media. According to William, the chance encompasses: first, social media can improve accessibility as it allows citizens to reach out to political leaders through different channels, second, social media can facilitate the dissemination 
of information for decision-making and the transfer of knowledge to the citizens, third, social media can provide platforms for discussion of pertinent issues between citizens and their leaders and among the citizens themselves, fourth, social media can facilitate effective networking among the citizens and the creation of different forms of organisations and communities, fifth, social media can provide avenues for more participatory, inclusive and deliberative processes of decision-making, sixth, social media can mobilise citizens around a cause and can spur social-political action. While the challenge is: firstly, accessibility may be impeded by a number of barriers such as poor infrastructure, poor literacy, cultural apprehension to new technologies, or profit interests, secondly, there appears to be a generational gap, with the younger generation making much more use of the opportunities of the internet and social media, thirdly, some observers see a tendency of the state to try to monitor, regulate or even block social media in a way that may threaten the freedom of expression online, fourthly, social media has increasingly become a channel for different forms of offenses and so-called "cybercrime"- such as "cyber-bullying", stalking, defamation, spread of false information and inciting messages, fifthly, social media increase the trend of "information overload" which makes it harder to filter out relevant and useful information and can lead to "social fragmentation" and "digital isolation" (Kamp, 2016, p. 7-8).

Responding to the statement above, the advantages and challenges of using new media, especially social media, cannot be separated from its role in giving and receiving information. The flow of information is so dense, resulting in a condition called the information society. This is the condition of society in the digital era today. People become heavily dependent on information every second and minute in their daily lives. Becla in the journal Information Society and KnowledgeBased Economy-Development Level and The Main Barriers-Some Remarks explained that the notion of the information society was introduced Tadlo Umeaso in 1963. He defined the information society as the society getting informed through the computer. The first group of definition which one can name "technological" came into being this way. The influence of technology on people's lives is mentioned by Martin Bangemann as "the revolution based on the information, which is a picture of human knowledge". Technological progress makes possible to process, storage, regain, and pass the information, in every possible form - verbal, written, or visual - unrestricted by distance, time and volume (Bangemann, 1994, as cited in Becla, 2012, p. 126).

Borrowing the term "revolution based on the information" mentioned by Martin, certainly not only related to the geographical aspects in which the technology can merge the boundaries of distance and time. It also includes aspects of the behavioral revolution, lifestyle, and the mindset of people, which is currently heavily influenced by the information they consume through new media. One illustration of the change has been explained by Dr. William Tayeebwa above about cybercrime that allows anyone to commit an information crime, either spreading false news to slander a person or particular group, spreading radical information, and so on.

\section{Filter Bubble Effect}

The main point that can be captured from the role of social media and its relation to the current state of digital society is access to information. The access generates several advantages and challenges like statement of Dr. William Tayeebwa before. There are many advantages gained when using social media, information from different regions and even countries that are so abundant, long distance communication is made easier, and so on. But 
that is not less important to note here is, the challenge of using social media itself. In one aspect, William mentions that the challenge of using social media is social media increasing the trend of "information overload" which makes it harder to filter out relevant and useful information and can lead to "social fragmentation" and "digital isolation". The information is so abundant that it makes it more difficult for people to distinguish what is right, what is wrong, and what is useful to them. Moreover through the click and like features, social media is able to present similar information based solely on the interests or likes of users, without considering the truth. This condition is very dangerous. Referring to William's terms, when a person consumes similar information or only based on single point of view continuously, he will experience digital isolation or can be said as a filter bubble effect.

In 2011, Eli Parisier released The Filter Bubble: What the Internet Is Hiding From You. In this book, Parisier explains how the internet search engines and their algorithms are creating a situation where users increasingly are getting information that confirms their prior beliefs (In Holone, 2016, p. 298). Adam (2017, para. 10) also explains that Eli Pariser, an internet activist, look no harmful irregularities of the system algorithms. The algorithm eventually create a "big bubble" that makes someone intellectually isolated. That is, when a person never see a different perspective of another person, then it is likely he is to drag on very large in its own judgment.

Prakash (2016, p. 18321) confirms this opinion that filter bubble is the result of web personalization and as a result the user get isolated from the views which he did not agree. The problem which lies here is that the user's likes and dislikes are guessed by algorithms which apply personalized search and sometimes relevant information for the user may be hided. Therefore, Prakash (2016, p. 18321) describes what he meant by web personalization. Web personalization is the process of customizing a website to the needs of each specific user or set of users, taking advantage of the knowledge acquired through the analysis of the user's navigational behavior. Integrating usage data with content, structure, or user profile data enhances the results of the personalization process. Ultimately, we can say that web personalization is done to provide each user their personal web.

What is meant by Prakash above can be felt through a number of social media like Instagram, YouTube, and Facebook. According to Guy et al., (2010, p. 194), in recent years, quite a few personalized recommendation services for social media have emerged. For instance, StumbleUpon1 is a personalized recommender engine that suggests web pages based on a user's past ratings, ratings by friends, ratings by users with similar interests, and topics of interest selected by the user from a list of nearly 500 subjects.

The term of filter bubble, has a similar meaning to black hole. Black hole is the online isolated field of communication where critical views and transparency are avoided. It is used to describe relatively closed social networks representing particular viewpoints on health (anti-vaccination), society (Anders Behring Breivik, white supremacy, and similar), religion (apocalyptic visions in relation to on-going incidents, for example, the last Ebola breakout or AIDS in the 1980s) (Hansen et al., 2017, p. 81)

Previous research in this regard explained that the search history is more effective in providing information to the user recommendation. It means that when we write a keyword in the search field, social media will record the traces are then such information will emerge in our social media pages. Or it could just as in the case above, a click on a particular post, subsequent postings from the same source or the like will continue until there are no clicks from us. Freyne et al. (2010, p. 280), in a journal 
Social Networking Feeds: Recommending Items of Interest, shows that harnessing the browsing patterns of users, what and whom they view, are more accurate predictors of relevance than what actions they carry out or with whom they communicate.

\section{Persecution Act in Social Media}

As result of filter bubble, many persecutions act in social media. Just based on his point of view, it is not uncommon for anyone to commit a persecution against another person or group. Persecution term is defined in Indonesian dictionary as hunting arbitrary one or a number of residents, and hurt, be troubled, or crushed (www.kbbi.web. id, 2017, para. 1). Rohmatin (2016, p. 134) also pressure the same thing, namely maltreatment systematic persecution committed by an individual or a group against other groups. Reinforced by Gummow J, the action of persecuting or pursuing with enmity and malignity: the infliction of death, torture or penalties for adherence to a religious belief or an opinion as such, with a view to the repression or extirpation of it; the fact of being persecuted; an instance of this... (in Vrachnas, et al., 2012, p. 227).

Of the three opinions above are similarities in defining acts of persecution. Some of the points that should be highlighted is related to the mistreatment of persecution against individuals or groups and there is an effort both physical and psychological harm. It is quite possible to do in social media that defines as "medium in internet that enable users to present and express their selves or to interact, to work together, to share, to communicate with other users and building social bounding virtually" (Nasrullah, 2015, as cited in Jamilah et al., 2016, p. 924). When someone has a belief or ideology that is opposed to the ideology of others and want to make it the same, it would be easy to do through social media. And persecution is a negative step to get those similarities.

\section{Public Sphere and Actor Rational Action}

Based on some theories above, from social media and society in the digital age, filter bubble effect and persecution act, it should be underlined that all this cannot be separated from the public sphere theory of Habermas. What makes the author's reason link some of these concepts with the concept of public sphere is the existence and role of social media. Social media is a form of public sphere in this era. Therefore, social media has fulfilled the criteria of public sphere that is meant by Habermas, namely the public sphere must be open and accessible to all, and in the public sphere of all has equal voice, with influence determined by the force of reason.

Social media provides an opportunity for anyone to participate and express an opinion. Moreover, in social media there is no categorization of whether they are government officials or ordinary people, all have the right to argue. Unfortunately, though structurally, social media has conformity to the concept of public space, substantially, it is not. The public sphere of Habermas emphasizes rationality in expressing opinions. There are various reasons and points of view put forward, thus creating a critical discussion, the best argument that will be taken. But not so with social media as the public sphere today. Through the concept of a bubble filter proposed by Eli Pariser, social media can lead one to isolate in his own viewpoint. And, ultimately, the condition triggers the act of persecution against another person or group that is a reflection of the condition of society in the digital age today.

The relationship between the public space and the actors' rational actions is clearly described by Gunaratne (2006, pp. 6-7). He emphasized the battle between the lifeworld realm and system sphere. The system is a territory controlled by state or government forces that have a policy with lifeworld domains filled by the public with critical argument 
through discussion in the public space. Eventually, Habermas (1981/1984) developed the notion of communicative rationality based on an in-depth reading of what he originally termed "universal" pragmatics and implanted the public sphere in the lifeworld realm, as opposed to the system realm, of society built into his communicative action theory (as cited in Gunaratne, 2006, p. 6). From the explanation, it can be said that the lifeworld aspect consists of civil society who conducts critical dialogue or social dialogue through its communicative action in correction or even against state policy, while in the realm of system, filled by governmental authority, using instrumental or strategic action rationality to impose his interest in society in the lifeworld realm. Therefore, in his explanation, Gunaratne (2005, p. 7) mentions that this uncoupling gave rise to the pathologies of modernity, or "colonization of the lifeworld".

\section{Methods}

The research method used is literature research. Literature research methodology is to read through, analyze and sort literatures in order to identify the essential attribute of materials. Its significant difference from other methodologies is that it does not directly deal with the object under study, but to indirectly access to information from a variety of literatures, which is generally referred to as "non-contact method" (Lin, 2009, p. 179). Based on the concept, the initial step of this paper is to formulate the first topic to be discussed. Then look for related theories or literature to answer and analyze the topic.

\section{Result}

Of the several theories already mentioned and based on the literature research method used by the author, then the following are the results obtained through the correlation between theories to answer the issues to be discussed later.

\section{Persecution Act in Social Media as Filter Bubble Effect: Overview of Digital Society Today}

Referring to the statement Gummow that the action of persecuting or pursuing with enmity and malignity: the infliction of death, torture or penalties for adherence to a religious belief or an opinion as such, with a view to the repression or extirpation of it; the fact of being persecuted; an instance of this... (in Vrachnas et al., 2012, p. 227). Compliance with the beliefs or opinions referred to above may be due to personalization of the web on social media or the so-called bubble effect filter. When we like or click a post, then on the next occasion the posting of the account reappears on our media homepage. Until finally the information bias occurs. As an explanation of Eli Parisier in The Filter Bubble: What The Internet Is Hiding From You that the internet search engines and their algorithms are creating a situation where users increasingly are getting information that confirms their prior beliefs (Holone, 2016 , p. 298). Luckily if the information contains a positive charge. If, on the contrary, one tends to follow continuously radical or extremist information, he may commit an act of persecution through hoaxes or other means, to equate views. Related to this, Nukman Luthfie, a social media observer, told to www.bbc.com (2017, para. 9), "the core algorithm is the fun of the user, so if we use our Facebook it's actually, in our time line it's contents that's it. Although we have 5000 friends for example, our time line content is the person-that's it. Content and friends, we often respond to, whether we like and we reply or content we share. "

Persecution act as a filter bubble effect is explained by Setiawan (2017, pp. 292-293) from the standpoint of communication barriers. He referred to the opinion of Onong Uchjana Effendy (2003) that communication barriers occur due to several things:

Firstly, mechanical disturbances in which the occurrence of interference in communication 
channels or physical noise, this interference is more towards the medium used in communicating, like a double voice on radio because of the waves that coincide, or the boisterous noise of the audience when people make a speech.

Secondly, because of semantic disorder. This type of disorder is concerned with the notion of actual words or changes in the meaning of words. Symbols of the same words have different meanings for different people.

Thirdly, because of interest (interest). Factors of interest will also hinder effective communication, because the importance of the communicant that makes the communicant will be selective in receiving and responding to messages. People will be aroused by messages that become their needs.

Fourthly, barriers due to motivation (motivation). The motivation factor of the communicant will also affect the level of awareness, attention, and stimulus to the message conveyed by the communicator. More appropriate, the message with one's motivation, higher the level of intensity and attention.

Fifthly, the obstacle due to prejudice. Prejudice is a severe obstacle to the communication process, if not anything communicant has been suspicious both to communicators and messages to be delivered, the the communication will not run effectively.

The five obstacles presented above, two of which can be used as one of the causes of the emergence of the persecution act as a filter bubble effect. Departing from ignorance of anything, one can take sides due to the personalization of the web. So when they already have a certain belief or view, they will be more selective in choosing information to strengthen it. And this is what is meant by Onong as a factor of interest and motivation. Communication is not effective because someone tends to ignore information that is not in accordance with the interests and needs.

From that condition, it falls into the challenges of using new media technologies as defined by Dr. William Tayeebwa that social media has increasingly become a channel for different forms of offenses and so-called "cybercrime" - such as "cyberbullying", stalking, defamation, spread of false information and inciting messages, and social media increase the trend of "information overload" which makes it harder to filter out relevant and useful information and can lead to "social fragmentation" and "digital isolation" (Kamp, 2016, p. 8). Spreading false information, inciting through messages, and digital isolation is the trigger of filter bubble effect in social media, a person or a particular group can freely spread its ideology, like a radical ideology that causes persecution of others. Nath (2009, p. 5 ) confirms this by stating, the exchanges of information in these instances through an ICT infrastructure. According to Nath, or a more radical idea of information super highways, largely facilitated by technology have been the basic tenet of an information society.

Social change of society as a result of the use of new media, has been predicted by Martin Bangemann that that the information society is "the revolution based on the information, which is a picture of human knowledge" (Bangemann 1994 as cited in Becla, 2012, p. 126). With information, people create their own world though not necessarily true. This condition is attached to the term "post-truth", which explains how in the information age, truth is often ruled out. Post-truth is an adjective defined as 'relating to or denoting circumstances in which objective facts are less influential in shaping public opinion than appeals to emotion and personal belief (Lambert, 2016, p. 63). In addition, in www. remotivi.or.id (2017) it is explained that Ralph Keyes in his book The Post-truth Era (2004) and comedian Stephen Colber popularized the term related to post-truth that is more or less truthiness as something as if true, though not true at all. Excessive information and social media's ability to select information based 
on user preferences leads them to a digital isolation, a bias of facts and reality. This is the condition of today's digital society. And the persecution act becomes a proof. Both extremist and private groups with deep-rooted convictions tend to do so. The important role of social media as an interactive medium that is easily accessible every day and even every second, increases the likelihood for individuals or groups to resist other truths. According to Lambert (2016, p. 63), scholars have tried to explain the factors that have caused this phenomenon of post-truth. The easy access to social media, blogs and internet stories are largely to blame.

\section{The Substantial Shift of Public Sphere and Actor Rational Action}

When associated with Juergen Habermas's public sphere concept, the first requirement is that public sphere must be open and accessible to all. In it, there is a critical discussion in response to public issues. This is relevant when associated with digital media. Introducing people to the internet brings a structural shift in the public sphere, especially its geographical aspects. Discussions and critical debates that are central components of the Habermas concept can be undertaken by various circles with no limited distance and time. If Habermas describes the public sphere with a forum where many people gather and discuss together, then in the context of new media today, people in one area with another can do so as if they meet face-to-face. According to Crack (2007), the contemporary information society and knowledge industries are characterized with the removal of all the temporal and spatial barriers to distanced communication with the help of information communication technologies (ICTs). A structural precondition of transnational public spheres is communicative networks to enable broad participation across state borders (Khan et al., 2012, p. 44). The new public sphere is emerging out of the digital gadgets starting from a 'computer' then connecting them into 'Network', which started within a building, then cities, states and finally 'global-networks' came up with the gadget of 'Internet', a global platform giving every citizen an opportunity to become an 'international-citizen' (Chan \& Lee, 2007, in Khan et al., 2012, p. 44).

Unfortunately, when viewed in the current context, social media as a part of digital media, it causes a substantial shift in the public sphere through filter bubble effect that removes dialogue and critical discussion and finally the act of persecution is easily done. Social media keeps them chained at their own point of view without any discussion or debate with other points of view by consuming the same information continuously in social media, especially negative information, can cause a person or group to be provoked to have the same point of view so as to enable them to commit in violence or intimidation against others. Especially when the layman who does not know anything, with the exposure is so strong, can be made believe. They will not seek to prove or compare with other information and sources. Though the truth was obtained from the objective search results as a form of critical discussion from the users of social media. Such statements of Gooch (2017, p. 14), in fact, truth requires the analysis of objective facts and a discussion of the evidence-requirements that bestow it with great value which professionals in any field have a duty to preserve.

Responding to this problem, Fuchs (2014, p. 61) attributed it to capitalism. He states that capitalism is the basis for the emergence of modern society. Social media, like Facebook, Twitter, WhatsApp, and all its types, can not be separated from those influences. With the initial goal of profit, global media companies have managed to reach out and attract markets across the country. Capital domination then penetrates to state autonomy and culminates in the private authority of civil society. That 
means, the presence of digital media makes people have full authority over public issues. And this is the characteristic of modern society.

The point that needs to be underlined from statement above is that in modern society, they have power over the means, including social media, allowing them to control the movement of information. Information on public issues is widely disseminated in social media which then through the media, public opinion and ideology can be directed by certain parties according to their interests. Therefore, Fuchs (2014, p. 61) adds that as modern society is based on structures of accumulation and a separation of roles within different realms, there are conflicts of interest over the control of property, collective decisions and meanings that can result in social struggles. Economic, political and cultural roles in modern society are organized in the form of classes, parties and political groups, and communities of interest that compete over the control of property/surplus, collective decision, and social meanings.

The relevance of the concept proposed by Fuchs above with the main issue in this paper lies in the different situations. If something is public, it is "open to all" (Habermas, 1991, p. 1 ). The task of a public sphere is that society can become engaged in "critical public debate" (Habermas, 1991, p. 52). The public sphere would therefore require media for information and communication and access by all citizens. The logic of the public sphere is independent of economic and political power (Habermas, 1991, p. 36): "Laws of the market (...) (are) suspended as were laws of the state" Habermas thereby stresses that the public sphere is not just a sphere of public political communication, but also a sphere free from state censorship and from private ownership. It is free from particularistic controls (as cited in Fuchs, 2014, p. 60).

The concept proposed by Habermas above is in a situation where capital forces have not yet dominated the global market. The mass media that existed at that time has not mobilized the public to have the authority and even the full power over the choice of information. So, Habermas still emphasizes the independence and neutrality of the public sphere, without the political economic interests in it. Unlike the condition of modern society today. Social media as a representation of public sphere in the digital age, no longer neutral. Social media can take sides, depending on the interests of the consumer. When they want to affirm their belief, social media is able to provide supportive information. Conversely, when they want to influence others to be equal to their beliefs and interests, social media is also able to provide that facility.

Thus, the critical debate in Habermas's public sphere leading to consensus, the best argument to be accepted, has shifted. Habermas's shadow is a group of people sitting together, conducting discussions to reach a consensus on public affairs. But what happens now is social media as a public sphere, it is very easy to present a variety of information by only loading one point of view according to user preferences and through click and like method. In fact, if adjusted to the ideal concept of public sphere, although there are features of click and like, social media should remain neutral (not only neutral from global interests or the state, but also personal or group interests) by providing facilities for information from various points of view can emerge. They will be trained to choose which information is true and not the absolute truth, according to their own convictions.

Previously, it has been explained that there is a shift in the concept of public sphere, according to Habermas with the current context. The public sphere in question can be attributed to the actor's rational action it installs. Habermas's conviction that human action or social interaction within a society does not occur arbitrarily but is essentially rational 
(Hardiman, 2009, p. 34). Among the two types of rational action are instrumental rationality and communicative rationality, debates and critical conversations to reach a consensus on the basis of the best argument included in communicative rationality. While the act of persecution and the facilities provided by social media in creating a bubble effect filter is an instrumental rationality.

Although equally included in rational action, according to Hardiman (2009, p. 36), in strategic action people use language not as a medium of understanding, but as a tool to impose the will. A tool for imposing will through words or even violence can be used to generate consensus. But one can not recognize such consensus as legitimate. It is for this reason that Habermas considers communicative actions (Handeln's kommunikatives)-means: actions directed at consensus-more fundamental than strategic action to produce social coordination mechanisms. For indeed in rationality or communicative action, there is a discussion of claims of validity, which includes truth claims, honesty and accuracy (Hardiman, 2009, p. 37).
In the public sphere there should be discussion from multiple points of view, rather than highlighting personal beliefs and rejecting the other truth.

If the picture above shows how the consensus consists of several claims, then it is not so in instrumental rationality. Someone affected by filter bubble in social media and finally dare to act persecution, only in the subjective world itself. One example is explained by Azali (2017, p. 5) that the FPI members and sympathisers have grown savvy in using digital media to systematically identify and harass those they disagree with, both online and offline. In this condition, a person judges something only from his perspective does not seek to find other evidence (claims of truth) nor confirm to various parties (claims of accuracy). So it can be said that social media as a public sphere can be a container of instrumental rationality. Habermas (1984, p. 285) talks about instrumental action as a nonsocial action oriented towards success or control (as cited in Kernstock \& Brexendorf, 2009, p. 395).

Figure 1.

In a communication taken three kinds of performative attitude toward the world. Consensus can be achieved only if all three validity claims that simultaneously met.

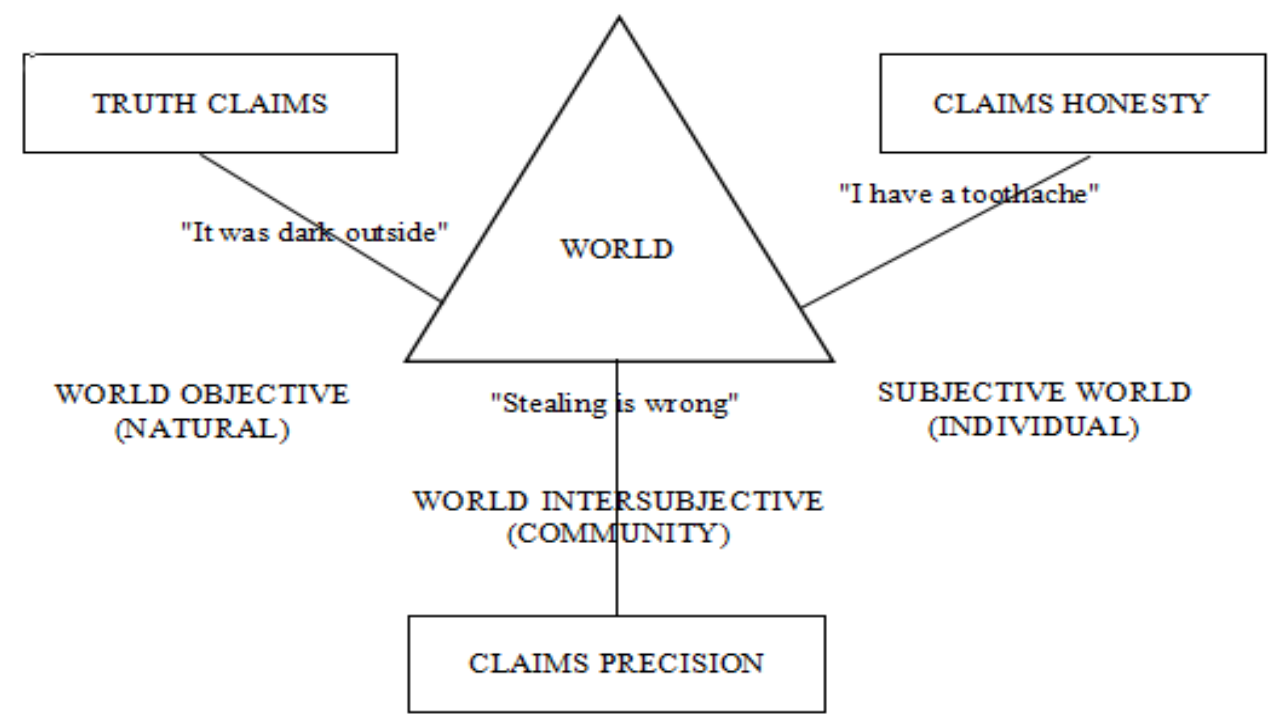

Source: Hardiman, F., B. (2009, p. 37) 


\section{Discussion}

From the above theoretical explanation, it can be attributed to one big case that has just been the world's attention is about the theft of Facebook user data by Cambridge Analytica. There are two cases behind Cambridge Analytica stealing user data. Facebook is Donald Trump's winning campaign in the 2016 presidential election of the United States and affecting users in the Brexit referendum. In the Trump case, for example on www.nytimes.com website explained that Cambridge Analytica, a political data firm hired by President Trump's 2016 election campaign, gained access to private information on more than 50 million Facebook users. The firm offered tools that could identify the personalities of American voters and their influence behavior (Granville, 2018, para. 2). Also, it was added by www.theguardian.com that a wholly-owned company has revealed to the Observer how Cambridge Analytica - a company owned by the hedge fund billionaire, Robert Mercer, and headed at the time by Trump's key adviser, Steve Bannon - used personal information taken without authorization early 2014 to build a system that could profile individual US voters, in order to target them with personalized political advertisements (Cadwalladr \& Harrison, 2018, para. 2).

Both cases explain how social media as a public sphere that basically has a concept about the occurrence of critical and rational discussion actually makes someone shackled in his own belief and truth. And Trump's case is one proof that by putting a pro ad for Trump on Facebook, it can increase the number of supporters and ultimately give the victory to the presidential election. The public who initially did not understand or did not even support Trump with such powerful media exposure, made them turn to support (it must be admitted that for US presidential election 2016, Facebook is very subtle in shaping polarization in society).

And just like any other election, when the public has made a choice, let alone fanatical of a certain character allows them to do everything, including persecution act, one of which is manifested through fake news in social media. Allcott \& Gentzkow (2017, p. 212) writes that following the 2016 election, a specific concern has been the effect of false stories - "fake news" as it has been dubbedcirculated in social media. Recent evidence shows that: 1) $62 \%$ of US adults get news on social media (Gottfried and Shearer 2016); 2) the most popular font news mainstream news stories (Silverman 2016); 3) many people who see them (Silverman and Singer-Vine 2016); and 4) the most discussed font news stories tended to favor Donald Trump over Hillary Clinton (Silverman 2016). Putting these facts together, a number of commentators have suggested that (Parkinson's 2016; Read 2016; Dewey 2016).

This case can be attributed to Fuchs's theory of connecting modern society with the present presence of social media with capitalism. Habermas, with the concept of public sphere that emphasizes critical discussion see the public sphere is still within the neutral limit. While Fuchs judge that in the modern era, especially with the social media, political economy has entered into it. So if Habermas creates a public sphere with his communicative actions as opposed to the system realm, it is now likely to shift to the control of the capitalist side. That means there is a tendency of the system realm to be dominant over the lifeworld realm. And this is not in line with the original intention that Habermas's critical theory is an attempt to emancipate the lifeworld from system "colonization" through the revival of an uncoerced and unrestricted public sphere operating on the "universal" pragmatics of communicative rationality (Gunaratne, 2016, p. 7).

\section{Conclusion}

The filter bubble in social media is one of the causes of persecution of someone or group against someone and other groups. 
The filter bubble takes place through web personalization where the algorithm on social media allows one to consume the information they like only. So there is bias information in it. When viewed from the context of today's digital society, the condition is a revolution based on information. Information has brought so great a change, not only in the geographical domain by melding distance and time, but also changing all aspects of life, especially in terms of the mindset and ideology of society. Post-truth era becomes a proof that someone can be shackled in the beliefs and ideologies it creates itself.

While in the concept of public sphere, Habermas, which emphasizes on rationality and critical discussion among members, the phenomenon that occurs now actually shows a substantial shift. With the filter bubble effect, it can be said there is no critical discussion conducted by someone or a particular group. They take for granted information on social media without compromising, confirming, or seeking other evidence to support their beliefs. The substantial shift can also be attributed to the actors' rational actions. Habermas in the concept of public sphere, wants a critical discussion of validity claims that include claims of accuracy, truth, and honesty. This action he then calls communicative rationality. Discussions that lead to consensus without coercion from others. Unlike the case with social media as a public sphere today. Social media actually provides facilities for the occurrence of strategic action or instrumental rationality, a control effort of someone to have others have the same ideology with him. Although there has been no empirical research, this article tries to offer a new discussion about the function of social media as a public sphere and all the attributes of action in it. Therefore, the suggestion for the future is that further research is needed in this regard to obtain strong evidence and objective facts on the ground.

\section{References}

Adam, A. (2017). Filter bubble: Sisi gelap algoritma media sosial. Retrieved December 17, 2017, from https://tirto.id/ filter-bubble-sisi-gelap-algoritma-mediasosial-cwSU

Allcott, H., \& Gentzkow, M. (2017). Social media and fake news in the 2016 election. Journal of Economic Perspective, 31(2), 211236. doi: $=10.1257 /$ jep.31.2.211

Arti Persekusi. (2017, December 17). Retrieved from https://kbbi.web.id/persekusi

Azali, K. (2017). Fake news and increased persecution in Indonesia. ISEAS Yusof Ishak Institute, 61, 1-10. Retrieved from https://www.iseas.edu.sg/images/pdf/ ISEAS_Perspective_2017_61.pdf

Bank, N., Z. (2014). Social media and its effects on individuals and social system. Human Capital Without Borders: Knowledge and Learning for Quality of Life. International Conference. Retrieved from http://www. toknowpress.net/ISBN/978-961-6914-093/papers/ML14-714.pdf

Becla, A. (2012). Information society and knowledge-based economyDevelopment level and the main barriers - some remarks. Interdisciplinary Approach to Economics and Sociology, 5(1), 125-132.

Bozdag, E. \& Hoven, J. v. d. (2015). Breaking The Filter Bubble: Democracy and Design. Ethics Inf. Technol, 1-17. doi: 10.1007/ s10676-015-9380-y.

Cadwalladr, C. \& Harrison, E., G. (2018). Revealed: 50 Million Facebook Profiles Harvested for Cambridge Analytica in Major Data Breach. Retrieved May 7, 2018, from https://www.theguardian. com/news/2018/mar/17/cambridgeanalytica-Facebook-influence-uselection

Caplan, R. \& Boyd, D. (2016). Who Controls the Public Sphere in An Era of Algorithms?. Mediation, Automation, Power, 1-19. Retrieved 
from https://datasociety.net/pubs/ap/ MediationAutomationPower_2016.pdf Charles, G.,-U. \& Rohwer, L., F. (2015). Habermas, the Public Sphere, and the Creation of a Racial Counterpublic. Michigan Journal of Race and Law, 21(1), 1-21. Retrieved from https://repository. law.umich.edu/cgi/viewcontent. cgi?referer=https://www.google.co.id/\& httpsredir=1\&article=1048\&context=mjrl Debora, Y. (2017). Kronologi kasus dugaan penistaan agama. Retrieved May 1, 2018, from https://tirto.id/kronologi-kasusdugaan-penistaan-agama-b457

Facebook FPI Picu Kekerasan atau Menyebar Pesan Kemanusiaan?. Retrieved January 31, 2018, from www.bbc.com/indonesia/ indonesia-42442733

Fuchs, C. (2014). Social media and the public sphere. Triple C, 12 (1), 57-101. Retrieved from http://www.triple-c.at/index.php/ tripleC/article/viewFile/552/529

Freyne, J., Daly, E., M., Berkovsky, S., \& Geyer, W. (2010). Social networking feeds: Recommending items of interest. Proceedings of the 2010 ACM Conference on Recommender Systems, 277-280. doi: 10.1145/ 1864708.1864766

Gooch, A. (2017). In pursuit of the truth. In UNO Magazine "The Post-Truth Era: Reality vs. Perception"(pp. 14-15). Spain: Llorente \& CUENCA.

Granville, K. (2018). Facebook and Cambridge Analytica: What you need to know as fallout widens. Retrieved May 7, 2018, from https://www.nytimes. com/2018/03/19/technology/Facebookcambridge-analytica-ex plained.html

Gual, M. (2017). Korban persekusi 'The Ahok Effect' tercatat mencapai 59 orang. Retrieved December 17, 2017, from https://www.cnnindonesia.com/ nasional/20170601163649-20-218744/ korban-persekusi-the-ahok-effecttercatat-mencapai-59-orang/.
Gunaratne, S. A. (2006). Public sphere and communicative rationality: Interrogating Habermas's Eurocentrism. Journalism $\mathcal{E}$ Mass Communication Monographs, 8(2). 4-115. doi: 10.1177/152263790600800201

Guy, I., Zwerdling, N., Ronen, I., Carnel, D., \& Uziel, E. (2010). Social media recommendation based on people and tags. SIGIR. Retrieved from https://www. research.ibm.com/haifa/dept/imt/papers/ guySIGIR10.pdf

Hansen, H., A., Bjorktomta, S., B., \& Svalastog, L. (2017). Digital Society generates New Challenges On Child Welfare Services. Croat Med Journal, 58, 80-83. Retrieved from http://neuron.mefst.hr/ docs/CMJ/issues/2017/58/1/cmj_58_1_ hansen_28252879.pdf

Hardiman, F., B. (2009). Demokrasi Deliberatif: Menimbang Negara Hukum dan Ruang Publik dalam Teori Diskursus Jurgen Habermas. Yogyakarta: Kanisius.

Holone, H. (2016). The filter bubble and its effect on online personal health information. Croatian Medical Journal, 57(3), 298-301. doi:10.3325/cmj.2016.57.298

Jamilah, I., Akbar, K., F., Gunawan, M., A., \& Marantika, S. (2016). Political communication, social media, and public sphere: An analysis to a phenomenon in Bandung towards Smart City. International Journal of Social Science and Humanity, 6(12), 923-928. doi: 10.18178/ ijssh.2016.6.12.774

Kamp, M. (Ed.). (2016). Reality Check Assessing The Impact of Social Media on Political Communication and Civic Engagement in Uganda. Uganda: Konrad Adenaur Stiftung:

Kernstock, J. \& Brexendorf, T., O. (2009). Implications of Habermas's "theory of communicative action" for corporatebrand management. Corporate Communications: An International Journal, 14(4), 389-403. doi: 10.1108/13563280910998745 
Khan, M., Z., Gilani, I., S., \& Nawaz, A. (2012). From Habermas model to new public sphere: A paradigm shift. Global Journal of Human Social Science, 12(5), 42-52.

Laidlaw, E., B. (2017). Online Shaming and The Right to Privacy. Journal of Laws, 6(3), 1-26. doi: 10.3390/laws6010003

Lambert, M. (2016). Post-truth era and impact on the science associated with sport and exercise medicine. S Afr J Sports Med, 28(3), 63. doi: 10.17159/2078-516X/2016/ v28i3a1838

Lin, G. (2009). Higher Education Research Methodology-Literature Method. International Education Studies, 2(4), 179-181.

Prakash, S. (2016). Filter Bubble: How to Burst Your Filter Bubble. International Journal of Engineering And Computer Science, 5(10), 18321-18325. doi: 10.18535/ijecs/v5i10.15

Rohmatin, T. (2016). Nilai-Nilai Pluralisme dalam Buku Pendidikan Agama Islam (PAI) untuk Sekolah Menengah Atas (SMA). Ilmu Ushuluddin, 3(1), 133-152.

Selamat Datang di Era Post-Truth. (2017, January 17). Retrieved from www. remotivi.or.id/kabar/345/SelamatDatang-di-Era-Post-Truth.

Setiawan, I. (2017). Kajian Yuridis terhadap Persekusi. Jurnal Ilmiah Galuh Justisi, 5(2), 291-299.

Vrachnas, J., Bagaric, M., Athula, P., \& Dimoploulos, P. (2012). Migration and Refugee Law: Principles and Practice in Australia ( ${ }^{\text {rd }}$ Ed.). New York: Cambridge University Press.

Yetkinel, O. \& Colak, M. (2017). The Effects of Transformation of Public Sphere with the New Media in Academy. EURASIA Journal of Mathematics Science and Technology Education, 13(8), 5009-5018. doi: 10.12973/eurasia.2017.00979a 